\title{
Implementation of a Nurse Leader Rounding Program in the Emergency Department
}

John Swanhorst

University of St. Augustine for Health Sciences, j.swanhorst@usa.edu

DOI: https://doi.org/10.46409/sr.RNSN6151

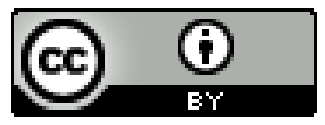

This work is licensed under a Creative Commons Attribution 4.0 License.

Follow this and additional works at: https://soar.usa.edu/scholprojects

Part of the Nursing Administration Commons

\section{Recommended Citation}

Swanhorst, J. (2021). Implementation of a Nurse Leader Rounding Program in the Emergency Department. [Doctoral project, University of St Augustine for Health Sciences]. SOAR @ USA: Student Scholarly Projects Collection. https://doi.org/10.46409/sr.RNSN6151

This Scholarly Project is brought to you for free and open access by the Student Research at SOAR @ USA. It has been accepted for inclusion in Student Scholarly Projects by an authorized administrator of SOAR @ USA. For more information, please contact soar@usa.edu, erobinson@usa.edu. 
Implementation of a Nurse Leader Rounding Program in the Emergency Department

\author{
John Swanhorst MSN MHA RN CEN CPEN
}

School of Nursing, University of St. Augustine for Health Sciences

This Manuscript Partially Fulfils the Requirements of the

Doctor of Nursing Practice Program and is Approved by:

Dr. Jennifer Mensik PhD RN NEA-BC FAAN

Dr. Darcy Copeland PhD RN

Approved: 3.24.2021 
University of St. Augustine for Health Sciences

DNP Scholarly Project

Signature Form

\begin{tabular}{|c|c|c|}
\hline $\begin{array}{l}\text { Student Last Name: } \\
\text { Swanhorst }\end{array}$ & $\begin{array}{l}\text { First Name: } \\
\text { John }\end{array}$ & lle Initial: \\
\hline \multicolumn{3}{|c|}{ J.Swail: } \\
\hline \multicolumn{3}{|c|}{ Title of DNP Project: } \\
\hline \multicolumn{3}{|c|}{$\begin{array}{c}\text { My signature confirms I have reviewed and approved this final written DNP Scholarly Project. } \\
\text { DocuSign electronic signature or wet signature required. }\end{array}$} \\
\hline Type Name in Blue Box Below & Signature & Date \\
\hline $\begin{array}{l}\text { DNP Project Primary Faculty: } \\
\text { Dr. Jennifer Mensik }\end{array}$ & 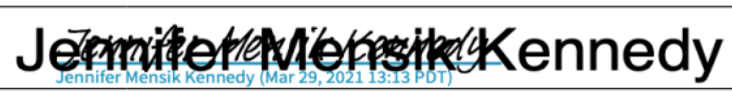 & $B t 24 \phi 2001$ \\
\hline $\begin{array}{l}\text { DNP Project Preceptor: } \\
\text { Dr. Darcy Copeland }\end{array}$ & $\frac{\text { Darcy Copeland }}{\text { Darcy Copeland (Mar } 30,202110: 37 \text { MDT) }}$ & BABBOD20121 \\
\hline DNP Project Preceptor: & & \\
\hline
\end{tabular}




\begin{abstract}
Practice Problem: The identified practice problem was the low "Likelihood to Recommend" patient experience survey scores within the ED at the identified project setting.

PICOT: The PICOT question that guided this project was "In ED patients (P), how does the implementation of Nurse Leader Rounding (I) compared to the prior state of no Nurse Leader Rounding (C) affect the "Likelihood to Recommend" top box score (O) within eight weeks (T)?" Evidence: In a review of 13 articles, the evidence consistently showed that Nurse Leader Rounding was a proven intervention for increasing patient engagement scores.

Intervention: Nurse Leader Rounding is defined as the department leader rounding on the patient within the department and providing: 1) feedback to the primary care team related to observations of care expectations by the leader and 2) in the moment service recovery if needed Outcome: The outcome of the project was a clinically significant increase in "Likelihood of Recommending" by $2.3 \%$ while no statistical significance in scores.

Conclusion: The conclusion of this project found that COVID-19 played a big part into the small increase in engagement scores. However, it did show that Nurse Leader Rounding, as an intervention, has the ability to increase patient engagement scores.
\end{abstract}




\section{Implementation of a Nurse Leader Rounding Program in the Emergency Department}

Emergency department (ED) patients are often seen due to an acute illness or traumatic injury. ED's are often the main entrance to the hospital inpatient units, and the stressful experience while in the ED can have lasting effects on the patient (Meade et al., 2010). This project paper will discuss the implementation of a nurse leader rounding (NLR) program and the effects it had on the overall experience of the ED patients.

\section{Significance of the Practice Problem}

The identified practice problem was the low "Likelihood to Recommend" patient experience survey score within the ED at the identified project setting. Patient experience scores have a direct correlation with a patient's health outcomes (Heath, 2016). The patient experience within the ED has lasting effects throughout the entire inpatient stay (Setia \& Meade, 2009). In 2006, the Center for Medicare and Medicaid Services (CMS) implemented the Hospital Consumer Assessment of Healthcare Providers and Services (HCAHPS) survey which is intended to measure the experience of the patient during their hospital stay (McFarlan et al., 2019). HCAHPS scores have a direct relationship with the amount hospitals are reimbursed for their services and thus their overall financial margins (McFarlan et al., 2019). This connection between HCAHPS results and reimbursement rates has many hospital leaders focusing on patient experience to make sure they are providing the best care and achieving high scores.

At the beginning of this project, the "Likelihood to Recommend" score is a top box score of $67.13 \%$ and a percentile ranking of $38 \%$ when compared to the Press Ganey database (J. Stewart, personal communication, May 27, 2020). A percentile rank of 38\%, indicated $62 \%$ of the over 2,000 Press Ganey hospitals had a higher patient recommendation score. This project was necessary to assist in achieving a higher "Likelihood to Recommend" score. The practice of 
tying patient experience to reimbursement rates for hospitals is relatively new: it began in 2006 with the creation of HCAHPS (McFarlan et al., 2019). However, it is a key indicator because positive experience by the patient suggests the patient will return and will not skip seeking medical care due to a negative previous experience (Tan \& Lang, 2014). This connection between patient experience and returning to the ED based off previous experience when needed speaks to both financial and patient safety organizational goals.

Hospitals must perform well financially if they want to keep providing care. Like any business, profitable margins allow for the company to retain employees and continue to provide its product (Betts et al., 2016). For hospitals, this product is caring for the community. Hospitals, just like any business, volume drives profits. Improved patient experience will increase patient loyalty, building a positive reputation and brand which will increase referrals provided by patients (Betts et al., 2016). A review of hospital profit margins and patient engagement scores showed that hospitals with top-box scores increased their net margin by $1.4 \%$ compared to hospitals with bottom-box scores (Betts et al., 2016, para. 5).

While financial performance is important, patient health outcomes should be the driving factor for improving patient engagement scores. While the exact reasoning is not yet known, increased patient engagement scores have a positive relationship with patient outcomes (Glickman et al., 2010). This could be due to the trust and open communication shared by the patient and clinic staff (Luy et al., 2013). It could also be because patients who had a positive experience were more likely to complete needed follow up visits and to return to the hospital if they had a negative side effect post discharge (Luy et al., 2013). 


\section{PICOT Question}

In ED patients (P), how does the implementation of NLR (I) compared to the prior state of no NLR (C) affect the "Likelihood to Recommend" top box score (O) within eight weeks (T)?

\section{Population}

The population for this project was the patients admitted to the 42-bed emergency department of a mid-sized, 220 bed hospital. More specifically, the population was the patients seen and discharged from this department that received and completed a patient engagement survey that was distributed by a third-party company.

\section{Intervention}

This project implemented the intervention of NLR to increase patient engagement scores within the ED. This intervention has been used both within the ED and inpatient settings and been shown to increase many aspects of patient engagement surveys while ultimately increasing the overall ranking of ED patient engagement scores (Littleton et al., 2019; McFarlan et al., 2019). In this paper, NLR is defined as the department leader rounding on the patient within the department and providing: 1) feedback to the primary care team related to observations of care expectations by the leader and 2) in the moment service recovery if needed.

\section{Comparison}

At the start of the project, the setting had no structured approach to NLR or patient engagement. While research findings support the ability of NLR to help raise patient engagement scores, this department had not implemented such a strategy (McFarlan et al., 2019). The comparison for this project was the previous state patient engagement scores prior to the implementation of NLR. 


\section{Outcome}

The intended outcome of this project was to see a statistically significant increase in ED patient engagement scores. Specifically, the "Likelihood to Recommend" question was tracked, as this question is used to compare overall patient engagement at the local, system, and national levels. The project team also identified two key domain questions that would be directly influenced by NLR. "Nurses concern to keep you informed about your treatment" and "How well the staff cared about you as a person."

\section{Timeline}

The timeline for this project was eight weeks starting on November $1^{\text {st }}$ and ending December $26^{\text {th }}$. It allowed the project team to develop the project details, educate needed stakeholders, implement the program, collect, and interpret data.

\section{Quality Improvement Framework \& Change Theory}

Employing a guiding framework and change theory keeps the project organized and structured. While there were many to choose from, it was important to select options that would work within the scope of the implemented project and that were supported within the sponsoring organization. The Kotter's Change Theory (1995) was selected for this project to assist in the execution of necessary change. The Kotter Change Theory (1995) and LEAN framework (1988) were selected for this project due to their routine use within the organization.

The LEAN framework supports reducing waste and limiting actions to only needed steps (Mostafa, et al., 2013). This reduction in extra steps ensures that standardization is used when possible. This standardization was seen within the literature and the LEAN framework was utilized throughout the project development to each required step was both within the literature but also needed so that nothing extra was completed resulted in additional time. 
While the LEAN framework was present throughout the project, the Kotter Change Theory (1995) was the driving theory to organize the implementation of this project. The Kotter Change Theory was being used and also taught to all staff as the sponsoring organization went through its High Reliability Organization journey. The Kotter Change Theory is an 8-step theory and framework that provided the project manager a structure from start to finish (Kotter, J., 1995). The project began after the organization had already established a strong significance for need, "Likelihood to Recommend" survey scores in the 38-percentile rank. It followed the steps of project team development, vision creation, working through communication and barrier removal (Kotter, J., 1995). The project team worked through short term goals and on sustainability measures that will continue the project after the short-term implementation and analysis. These steps were directly related to the Kotter (1995) model.

\section{Evidence Search Strategy}

A robust literature search was completed to support this project. The PICOT question was: "In ED patients (P), how does the implementation of NLR (I) compared to the prior state of no NLR (C) affect the "Likelihood to Recommend' top box score (O) within eight weeks (T)?" The three databases used were Google Scholar, CINAHL Complete, and PubMed. When searching, the following keywords were used: "emergency department," "patient engagement," "patient experience," "patient satisfaction," "nurse leader rounding," and "leader rounding." Inclusion criteria were articles written in English, published in 2009 or more recently, speaking to leader rounding on patients, peer reviewed research, and set setting within an acute care hospital. Exclusion criteria eliminated articles that spoke to nurse leader rounding on staff instead of patients, were outside of the acute care hospital setting, and were published before 2009. Once results from the initial search were gathered, the DNP student read abstracts. Articles 
that met both inclusion and exclusion criteria were then fully reviewed to analyze their appropriateness for the project.

\section{Evidence Search Results and Evaluation}

Using the previously mentioned search strategy, a review of three databases was completed. The initial search, presented in the Figure 1 by use of a PRISMA diagram, resulted in 43 articles for review (Moher et al., 2009). After removal of duplicates, 21 articles were left to review. Once a review of all abstracts was completed and inclusion and exclusion criteria were applied, 14 remained as evidence for performance of the intervention established for this project. Reduction from 21 to 14 articles resulted due to articles not meeting inclusion criteria and/or meeting exclusion criteria. Following these steps, this author was able to confidently say that all articles were reviewed from 2009 to 2020 related to NLR or Leader Rounding to improve patient engagement scores.

The SORT methodology was then used to grade individual articles and assign each a strength level based on type of research, outcomes, and consistency (Ebell et al., 2009). See Table 1 for article strength. The individual systematic review was reviewed and graded separately (see Table 2). A consistent message appeared that implementation of NLR had a direct effect on the increase of overall patient engagement scores. The consistent results and conclusions of the presented data resulted in a SORT grade of a B (Ebell et al., 2009). While consistent outcomes were found and large sample sizes were used, identified studies did not include higher level research, such as randomized control studies or meta-analyses. The research that was found was well done and did show a consistent correlation between NLR and patient engagement scores. This consistency confirmed a grade of B on the SORT grading system (Ebell et al., 2009). 


\section{Themes from the Evidence}

Three primary themes were identified to support this evidence-based project: a consistent relationship of NLR and patient engagement, a structured approach to rounding, and standard communication during all rounds.

\section{Consistent Relationship of NLR and Patient Engagement}

A major theme that was seen through the research was consistent and proper NLR resulted in increased patient engagement scores (Babaev, 2017; Baker, 2010; Gillam et al., 2017; Hudson-Covolo et al., 2017; Littleton et al., 2019; McFarlan et al., 2019; Morton et al., 2014; Pattison et al., 2017; Reid, 2017; Setia \& Meade, 2009; Sturdivant et al., 2020; Tan \& Lang, 2014; Tothy et al., 2018; Winter \& Tjiong, 2015). While there were slight differences in process, the NLR was judged to be an effective intervention for patient engagement improvement in all of the studies' results. This consistency provided substantial support for implementation of the intervention for increasing patient engagement scores.

\section{Structured Approach}

While variation occurred in the literature, a well-defined and structured approach was seen in many of the articles reviewed (Babaev, 2017; Hudson-Covolo et al., 2018; McFarlan et al., 2019; Morton et al., 2014; Sturdivant et al., 2020). Sturdivant et al. (2020) spoke to a welldefined, detailed process that assigned the acronym "PATIENT" (p. 159). Although the PATIENT process was not identified within all articles, others did address the same expectations of the need for a standard, consistent, and structured approach (Babaev, 2017; McFarlan et al., 2019; Morton et al., 2014). 


\section{Standard Communication}

Along with a structured approach, standard communication was a consistent theme seen throughout the articles reviewed (Gillam et al., 2017; Hudson-Covolo et al., 2018; Littleton et al., 2019; Reid, 2017; Setia \& Meade, 2009; Tothy et al., 2018). Gillam et al. (2017) and Littleton et al. (2019) mentioned using common communication based off specific questions within the patient engagement survey that needed the most improvement such as the need to keep patients updated or the curtesy of the staff. While the articles had differences in the communication used, the articles had commonality of requiring the leader to use standard communication during all rounds.

A review of the 13 articles indicated there were differences within the process, communication, and expectations of leaders during rounding. However, all of the studies reported the process of rounding increased the overall patient engagement score within the department. While consistent messaging was seen throughout all articles, no randomized controlled trials have been published that address NLR and its effect on patient engagement scores. The consistent findings through quality improvement studies and well documented outcomes give confidence NLR will be an appropriate evidence-based intervention to improve patient engagement scores.

\section{Practice Recommendations}

According to the completed literature search and presented results, NLR exhibited an evidence-based intervention for improving overall "Likelihood to Recommend" patient engagement scores within the ED (Babaev, 2017; Gillam et al., 2017; Hudson-Covolo et al., 2017; Littleton et al., 2019; McFarlan et al., 2019; Morton et al., 2014; Pattison et al., 2017; Reid, 2017; Setia \& Meade, 2009; Sturdivant et al., 2020; Tan \& Lang, 2014; Tothy et al., 2018; 
Winter \& Tjiong, 2015). While there was a lack of random control and meta-analysis studies addressing this topic, the evidence was consistent within multiple quality improvement projects and indicated that NLR was associated with significant increases in patient engagement scores. This consistency of intervention and outcome ensured that NLR would achieve the same desired outcome within this project. Therefore, the literature supported development of a standardized tool to ensure standardized questions and structure for the rounding leader. Standardization was consistent through the literature and ensured that the process was reliable (Babaev, 2017;

Hudson-Covolo et al., 2018; McFarlan et al., 2019; Morton et al., 2014; Sturdivant et al., 2020).

Within the literature, a direct relationship was seen between increased patient engagement scores, clinical patient outcomes, trust between clinicians and patient, and financial benefits to the organization (Bresnick, 2015 \& Heath, 2016). Due to these reasons and consistency within the available research, NLR was a supported intervention to increase patient engagement scores.

\section{Project Setting}

This project's setting was an urban, level one trauma center ED. The ED was within a 236-bed tertiary hospital located in Jefferson County, Colorado. The average patient within the department was 55 to 65years old, Caucasian, and male (J. Stewart, personal communication, May 27, 2020). The setting was the referral hospital for an extensive health system within Colorado made up of 17 hospitals.

A SWOT analysis was completed to identify strengths, weaknesses, external opportunities, and threats (see Table 3). Identified weaknesses and threats were mitigated where possible while strengths and opportunities continued. The strengths were the significant support of and motivation by the hospital's Chief Nursing Officer (CNO), and an external opportunity 
was the support from the system patient experience director. One weakness was the limited time of the unit leadership team. External threats were changing priorities within the system associated with COVID-19 due to changes in needs of both staff and patients. Leadership time constraints were mitigated by ensuring that leadership had dedicated time free of meetings supported by the CNO.

\section{Project Overview}

This project implemented an evidence based NLR program. The expected outcome was to increase the quality of patient rating of their experience during their stay in the ED. The mission of the program setting was "We extend the healing ministry of Christ by caring for those who are ill and by nurturing the health of the people in our communities" (Centura Health, n.d.). The project's expected outcome addressed and helped to fulfill the organization's mission.

The risk of meeting the project's short- and long-term objectives was related to the organization's priorities and the department leadership team's commitment. To be effectively implemented, NLR requires a significant time commitment from the department leadership. While the risk of leadership prioritization cannot be mitigated and must be accepted, the risk of department leadership time constraints was mitigated by effectively demonstrating the project's benefit, how daily tasks could be accomplished during NLR, and reserving dedicated time for rounding, free of meetings.

While the long-term objective is to increase patient engagement scores, the short-term objectives were to establish a NLR plan with the department leadership group that was both effective and sustainable. The long-term objective of increasing patients' experience while seeking care could only be met by meeting the short-term objective first. 


\section{Project Plan (Method)}

Kotter's Change Model was the framework for this project (Kotter, 1995). This model has proven success in establishing guidelines for large-scale changes across an organization (Appelbaum et al., 2012). This was also the change model promoted within the organization. The Kotter Change Model is an eight-step process that guided the project leader to gain urgency and anchor the change as standard work within the department (Kotter, 1995). The Doctor of Nursing Practice (DNP) student assumed the role of the project lead. The project team, which assisted in the implementation, was made up of department and hospital team members.

\section{Create a Sense of Urgency}

A meeting took place to understand the current state within the project setting and to create a sense of urgency. The project lead met with the system and local patient engagement leaders to understand current and future state expectations. Before the NLR program was implemented, the department was not meeting hospital or system-wide goals related to patient engagement. The department was also seeing increased competition across the market area as additional freestanding EDs and urgent care centers opened. The increase in patient engagement scores was therefore vital to the survival of the department.

\section{Build a Guiding Coalition}

The project lead developed a project team, which involved department leadership, the patient engagement manager, quality department leadership, department medical director, Press Ganey representative, and system patient engagement director. The project lead gained approval and support from the hospital's Chief Executive Officer (CEO), CNO, and Chief Medical Officer (CMO). Although development of the project was the project lead's responsibility, the project team was essential to provide expertise and support implementation. 


\section{Form a Strategic Vision and Initiatives}

The project lead created a strategic vision for the project: "To increase patient engagement scores within the ED by use of a sustainable NLR program.” This evidence-based approach to increasing patient engagement scores presented many challenges and opportunities for the project team.

In collaboration with the system patient experience director, a four-hour class was held to kick start the NLR program within the ED. The clinical nurse manager (CNM), assistant nurse managers (ANMs), and the hospital patient experience manager attended. This class reviewed literature findings related to the benefits of NLR, the understanding of the current state of the department, and the need for improvement. Activities included sharing the project expectations, job aids that were used, process expectations, role-playing to practice, and obtaining feedback.

Once IRB approval was gained, training was completed with the CNM and ANMs. The CNM and ANMs were allowed to practice NLR with actual patients and feedback with staff members. Once the CNM and ANM had time to practice before the project started, the CNM and ANMs were validated on their NLR adherence by the project lead using a validation tool (see Appendix A).

Once they were approved to continue, the CNM and ANM began NLR and data collection with the assistance of the project lead on the project start date. The project's timeline expanded over 45 weeks and included the development of the project proposal and ended with dissemination (see Appendices B through D). Once the project started, the project lead met weekly with the hospital patient experience manager, CNM, medical director, and quality director to review Press Ganey data and all collected data by the CNM and ANMs. Data were reviewed for completeness, and feedback was given based on the prior week's accomplishments. 
These weekly meetings continued throughout the project, and the project team continued to evaluate the project's status.

The data collected by the Press Ganey survey were, date of visit, "Likelihood to Recommend" daily survey results, "Nurses' concern to keep you informed about your treatment" daily survey results, and "How well the staff cared about you as a person" daily survey results. Data collected around NLR were the leader completing the rounding, date, and number of rounds completed.

\section{Communicate a Vision for Change}

Communication was an essential component of this process change. Communication was structured to ensure the project team understood the vision. The project lead developed the project's communication plan. Data were distributed weekly to the project team. This communication included the most recent Press Ganey scores, current NLR progress by the group, reiteration of expectations, and short-term wins.

\section{Enable Action by Removing Barriers}

As the project team worked through the process of the project, members identified barriers. These barriers included time constraints, increased COVID-19 numbers, COVID 19vaccination plans, leadership changes, and staff burnout. The project lead worked through these barriers and removed as many as possible to ensure the project could move forward and be successful. Removing barriers required collaborating with the department, local, system leadership, and other departments within the hospital. However, the COVID-19 pandemic and changes within leadership were barriers that could not be avoided. 


\section{Generate Short-Term Wins}

Frequently, in the writer's experience, projects can take many months to years before the end goal is achieved. This extended timeframe of work can cause stakeholders to become discouraged. By providing short-term goals, the stakeholders had short-term wins to celebrate as the process continues. These short-term wins motivated the group to work towards the final goal. This project had many short-term wins: completion of education and validation, the first week of data collection, four weeks of data collection, and six weeks of data collection. These milestones allowed continued celebration and encouragement through the project.

\section{Sustain Acceleration}

Once the project was completed, the continuation of the NLR was successful. The weekly project team meetings will continue. In these meetings, Press Ganey data will continue to be reported. Additionally, NLR numbers and findings will be presented Monday through Friday at the hospital operational huddle. Although the project lead will no longer serve the communicative role, reporting expectations will ensure sustainability and allow barriers to be presented and solved by department and hospital.

\section{Anchor Change}

To further support sustainability, anchoring the change into the culture of the department was needed (Kotter, 1995). This process began during the eight weeks of the project. The continued sustainability plan will assist in pushing the project forward. Culture changes take time, and this project intervention is no exception. The department leadership's daily and weekly accountability will ensure that this intervention becomes anchored into the department's culture for years to come. 


\section{Results}

This project's expected outcome was to see an increase in the patient engagement survey "Likelihood to Recommend" top box score. Data were collected externally by the third-party company Press Ganey and given to the project lead in a HIPAA compliant report by the host organization's patient experience manager. Baseline data were pulled from the eight weeks before the implementation of NLR. Data related to the numbers of NLR were collected during the implementation phase of the project. Six weeks after the completion of the project, patient engagement data was collected. This delay in collecting patient engagement data was required to allow all surveys to be completed and returned. See Table 4 for all collected variables.

\section{Descriptive Data}

The project completed NLR on 49 of the 56 implementation days or $87.5 \%$. During this time, three nurse leaders completed a total of 1120 rounds which resulted in rounding being completed on $17 \%$ of the 6,590 patients that sought care in the project setting during the implementation phase. $57.14 \%$ of days were compliant in rounding on $20 \%$ of patients that day and $41 \%$ of the days saw rounding on both the day and night shifts. During this time, 278 patient surveys were completed resulting in a top box score increase of $2.3 \%$ for "Likelihood of Recommending," $1.28 \%$ increase in "Staff cared about you as a person," and no change in the "Nurses kept you informed" question.

The implementation data were compared to pre-data using the generated survey. Specifically, the question "Likelihood of your recommending our Emergency Department to others" was the primary outcome variable being studied. The question could have been answered five ways; very poor, poor, fair, good, and very good. For this project, the project team evaluated 
the percentages within each response and looked for a statistically significant difference between the pre-and implementation results.

\section{Statistical Analysis}

To analyze data related to the patients' thoughts towards recommending the ED to others, an independent t-test was completed to look for significance in the change of the patient engagement questions. All three questions had $\mathrm{p}$ values indicating that there were no significant changes within the mean of patient engagement score and scores during the implementation (see Table 5).

Table 5

Survey Question Sig. Pre Implementation

\begin{tabular}{lccc}
\hline Survey Questions & M (SD) & M (SD) & P \\
\hline Likelihood of Rec. & $79.48(23.45)$ & $83.76(17.11)$ & .278 \\
Nurses kept you informed & $84.77(16.06)$ & $84.8(16.82)$ & .991 \\
Staff Cared about you & $84.76(15.44)$ & $86.14(13.24)$ & .617 \\
\hline
\end{tabular}

However, an increase of $2.3 \%$ within the question of "Likelihood to Recommended" has a clinical significance of improvement within the organizational goal looking to see a one to two percent increase over the year (J. Stewart, personal communication, May 27, 2020).

\section{Leader Rounding}

Additional variables were tracked related to the number of completed nurse leader rounds as a process measure that assisted in the program's progress. This measure guided the project team along to ensure that the intervention was being completed and followed. The project goal was to round on $20 \%$ of all patients presented for care within the ED each day. The tracking tool (see Appendix E) created by the project lead helped collect the completed NLR total. This 
compliance measure ensured that the project team and lead were completing the expected number of rounds.

A Point, Biserial Correlation test, was completed using the raw data from the Press Ganey survey and NLR data. The test showed no correlation for days that had the rounding numbers meet the $20 \%$ expectation and increased patient "Likelihood to Recommend" scores compared to days where compliance was not met (see Table 6).

Table 6

Point Biserial Correlations

\begin{tabular}{lccc} 
Combination & $\boldsymbol{r}_{\mathbf{p b}}$ & $\mathbf{9 5 \%} \mathbf{C I}$ & $\boldsymbol{p}$ \\
\hline $20 \%$ Compliant/Likelihood of Recommending & 0.24 & {$[-0.03,0.47]$} & .080
\end{tabular}

Any project has financial or budgetary aspects All included stakeholders and project team members were salaried, and there was no increase in cost due to the increased expectations. These new expectations and time commitments were absorbed into their expected roles and salaries.

\section{Impact}

The impact of this project was a sustainable intervention that will continue to drive improvements in patient engagement. During the implementation phase, department leadership made NLR part of the department expectation and standard practice. While results did not indicate statistically significant changes to overall patient engagement scores, NLR was adopted as a best practice throughout the project setting. Now that the implementation phase has been completed and COVID-19 is more controlled, the department leadership team has made NLR a high priority within their day-to-day work. Six weeks post-implementation, the department has increased their NLR to $30 \%$ of all patients consistently every day of the week and has seen an 
increase of $4 \%$ within the "Likelihood to Recommend" question since the implementation phase was completed.

The intervention will continue to be monitored for success through a weekly meeting with the department leadership and quality department to discuss the unit's patient engagement scores. Additionally, the department leadership will report out daily, Monday through Friday, in a hospital-wide safety huddle to speak to the number of rounds completed the day before. These two interventions will ensure that the NLR project continues in the long-term.

To ensure the rounding's validity, the department director will validate the department management team on their NLR techniques and ensure that consistency and expectations are met at the bedside. This validation will ensure the patient interaction is correct and the interaction with the staff members occurs post rounding.

\section{Dissemination Plan}

The project results were disseminated in multiple venues. First, a PowerPoint and verbal presentation took place at the hospital involving the project team, hospital executive team, preceptor, and department leadership. This presentation included the methodology required for the project, evidence of evidence-based practice related to the intervention, successes and barriers, and the results. The presenter discussed why NLR was a success even though the data did not support statistical significance. In addition to success and barriers, the project leaders gave feedback on how to increase the program's success moving forward. The executive team was given feedback about the need for managers to have dedicated time away from meetings to round within the unit and for resiliency training for staff due to the COVID-19 pandemic.

To share results with the greater community, a similar presentation was given to the department and will be presented at the health system evidence-based conference in the coming 
year. This is an annual conference that allows staff members within the system to present projects and results that have been completed showing evidence-based practice changes. Even though the project results did not show statistically significant improvement, dissemination to the system is essential to show that future work around NLR needs to continue in EDs within this system.

\section{Conclusion}

In this paper, an evidence-based plan was created to implement NLR as an intervention to improve patient engagement scores, specifically "Likelihood to Recommend" scores within the ED. This paper included the significance of the practice, the framework to be used, literature review findings, practice recommendations, evaluation of results, impact, and the dissemination plan.

During this project's implementation, the setting was dealing with the COVID-19 pandemic and did not see a statistically significant change within engagement scores. However, the $2.3 \%$ increase in the top box showed that the intervention did affect the patient's experience, which supported the decision to continue NLR within the department.

Patient engagement was shown to increase the financial margins of an organization and improve patient outcome. While NLR did not show a statistically significant change in patient engagement scores during this project's timeline, the literature supports continuing NLR within the project setting. As COVID-19 continues to be better controlled within the United States, NLR will continue to be a necessary intervention within the project setting. 


\section{References}

Appelbaum, S. H., Habashy, S., Malo, J., \& Shafiq, H. (2012). Back to the future: Revisiting Kotter's 1996 change model. Journal of Management Development, 31(8), 764-782. https://doi.org/10.1108/02621711211253231

Babaev, A. (2017). Nurse leader rounds: Effect on nurse - related patient satisfaction scores on two post-surgical units in an acute care facility. Medical \& Clinical Research, 2(3). https://doi.org/10.33140/mcr.02.03.02

Baker, S. (2010). Rounding for outcomes: An evidence-based tool to improve nurse retention, patient safety, and quality of care. Journal of Emergency Nursing, 36(2), 162-164. https://doi.org/10.1016/j.jen.2009.11.015

Betts, D., Balan-Cohen, A., Shukla, M., \& Kumar, N. (2016). The value of patient experience: Hospital with better patient-reported experience perform better financially. Deloitte Center for Health Solutions. https://www2.deloitte.com/us/en/pages/life$\underline{\text { sciences-and-health-care/articles/hospitals-patient-experience.html }}$

Bresnick, J. (2015). Medication non-adherence brings millions in avoidable costs. Health IT Analytics. https://healthitanalytics.com/news/medication-non-adherence-brings-millions$\underline{\text { in-avoidable-costs }}$

Centura Health. (n.d.). Mission \& values. Retrieved July 12, 2020, from https://www.centura.org/about-centura/mission-and-values

Ebell, M., Siwek, J., Weiss, B., Woolf, S., Susman, J., Ewigman, B., \& Bowman, M. (2004). Strength of recommendation taxonomy (SORT): A patient-centered approach to grading evidence in the medical literature. American Family Physician, 69(3), 548-556. https://www.aafp.org/afp/2004/0201/p548.html 
Gillam, S. W., Gillam, A. R., Casler, T. L., \& Cook, K. (2017). Increasing patient recall of nurse leader rounding. Applied Nursing Research, 38, 163-168. https://doi.org/10.1016/j.apnr.2017.10.013

Glickman, S. W., Boulding, W., Manary, M., Staelin, R., Roe, M. T., Wolosin, R. J., Ohman, E., Peterson, E. D., \& Schulman, K. A. (2010). Patient satisfaction and its relationship with clinical quality and inpatient mortality in acute myocardial infarction. Circulation: Cardiovascular Quality and Outcomes, 3(2), 188-195. https://doi.org/10.1161/circoutcomes.109.900597

Heath, S. (2016). How do patient engagement strategies cut healthcare costs? Patient Engagement HIT. https://healthitanalytics.com/news/medication-non-adherence-brings$\underline{\text { millions-in-avoidable-costs }}$

Hudson-Covolo, J., Rivers, R., \& Irwin, B. (2018). Daily intentional nurse leader rounding on patients. Journal of PeriAnesthesia Nursing, 33(1), 90-95. https://doi.org/10.1016/j/jopan.2017.11.005

Institute for Healthcare Improvement. (2020). Science of improvement: Testing changes. http://www.ihi.org/resources/Pages/HowtoImprove/ScienceofImprovementTestingChang $\underline{\text { es.aspx }}$

Kotter, J. (1995). Leading change: Why transformation efforts fail. Harvard Business Review. https://hbr.org/1995/05/leading-change-why-transformation-efforts-fail-2

Krafcik, J. (1988). Triumph of the lean production system. Sloan Management Review. https://edisciplinas.usp.br/pluginfile.php/5373958/mod_resource/content/4/krafcik_TEX TO_INTEGRAL.pdf 
Littleton, L., Fennimore, L., Fernald, C., \& Gonzalez, J. (2019). Effective nurse leader rounding improves the patient experience. Nursing Management, 50(10), 11-14. https://doi.org/10.1097/01.NUMA.0000580620.45628.cd

Lyu, H., Wick, E. C., Housman, M., Freischlag, J., \& Makary, M. A. (2013). Patient satisfaction as a possible indicator of quality surgical care. JAMA Surgery, 148(4), 362. https://doi.org/10.1001/2013.jamasurg. 270

McFarlan, S., O'Brien, D., \& Simmons, E. (2019). Nurse-leader collaborative improvement project: Improving patient experience in the emergency department. Journal of Emergency Nurses, 45(2), 137-143. https://doi.org/10.1016/j.jen.2018.11.007

Meade, C. M., Kennedy, J., \& Kaplan, J. (2010). The effects of emergency department staff rounding on patient safety and satisfaction. The Journal of Emergency Medicine, 38(5), 666-674. https://doi.org/10.1016/j.jemermed.2008.03.042

Morton, J. C., Brekhus, J., Reynolds, M., \& Dykes, A. (2014). Improving the patient experience through nurse leader rounds. Patient Experience Journal, 1(2), 53-61. https://doi.org/10.35680/2372-0247.1036

Mostafa, S., Dumrak, J., \& Soltan, H. (2013) A framework for lean manufacturing implementation. Production and Manufacturing Research, 1(1), 44-64. https://doi.org/10.1080/21693277.2013.862159

Moher, D., Liberati, A., Tetzlaff, J., \& Altman, D., (2009). Preferred reporting items for systematic reviews and meta-analyses: The PRISMA statement. PLoS Med, 6(7), e1000097. https://doi.org/10.1371/journal.pmed1000097 
Pattison, K. H., Heyman, A., Barlow, J., \& Barrow, K. (2017). Patient perceptions of sitting versus standing for nurse leader rounding. Journal of Nursing Care Quality, 32(1), 1-5. https://doi.org/10.1097/ncq.0000000000000214

Reid, S. (2017). Improving patient satisfaction scores with digital nurse leader rounding. Health Management Technology, 14. www.healthmgttech.com

Setia, N., \& Meade, C. (2009). Bundling the value of discharge telephone calls and leader rounding. JONA: The Journal of Nursing Administration, 39(3), 138-141. https://doi.org/10.1097/nna.0b013e31819894f1

Sturdivant, T., Herrin, K., Reynolds, M., \& Mestas, L. (2020). Improving patient satisfaction through a nurse leader-physician bedside rounding protocol: A pilot project. Nursing Economics, 38(3), 158-163. http://www.nursingeconomics.net/cgibin/WebObjects/NECJournal.woa

Tan, M., \& Lang, D. (2014). Effectiveness of nurse leader rounding and post-discharge telephone calls on patient satisfaction: A systematic review protocol. JBI Database of Systematic Reviews and Implementation Reports, 12(1), 23-32. https://doi.org/10.11124/jbisrir-2014-1256

Tothy, A., Sastry, S. K., Springman, M. K., Limper, H. M., Fahrenbach, J., \& Murphy, S. M. (2018). Transforming care through bedside leader rounding: Use of handheld technology leads to improvement in perceived patient satisfaction. Patient Experience Journal, 5(3), 41-46. https://doi.org/10.35680/2372-0247.1254

Winter, M., \& Tjiong, L. (2015). HCAHPS series part 2. Nursing Management (Springhouse), 46(2), 26-32. https://doi.org/10.1097/01.numa.0000460034.25697.06 
Figure 1

PRISIMA
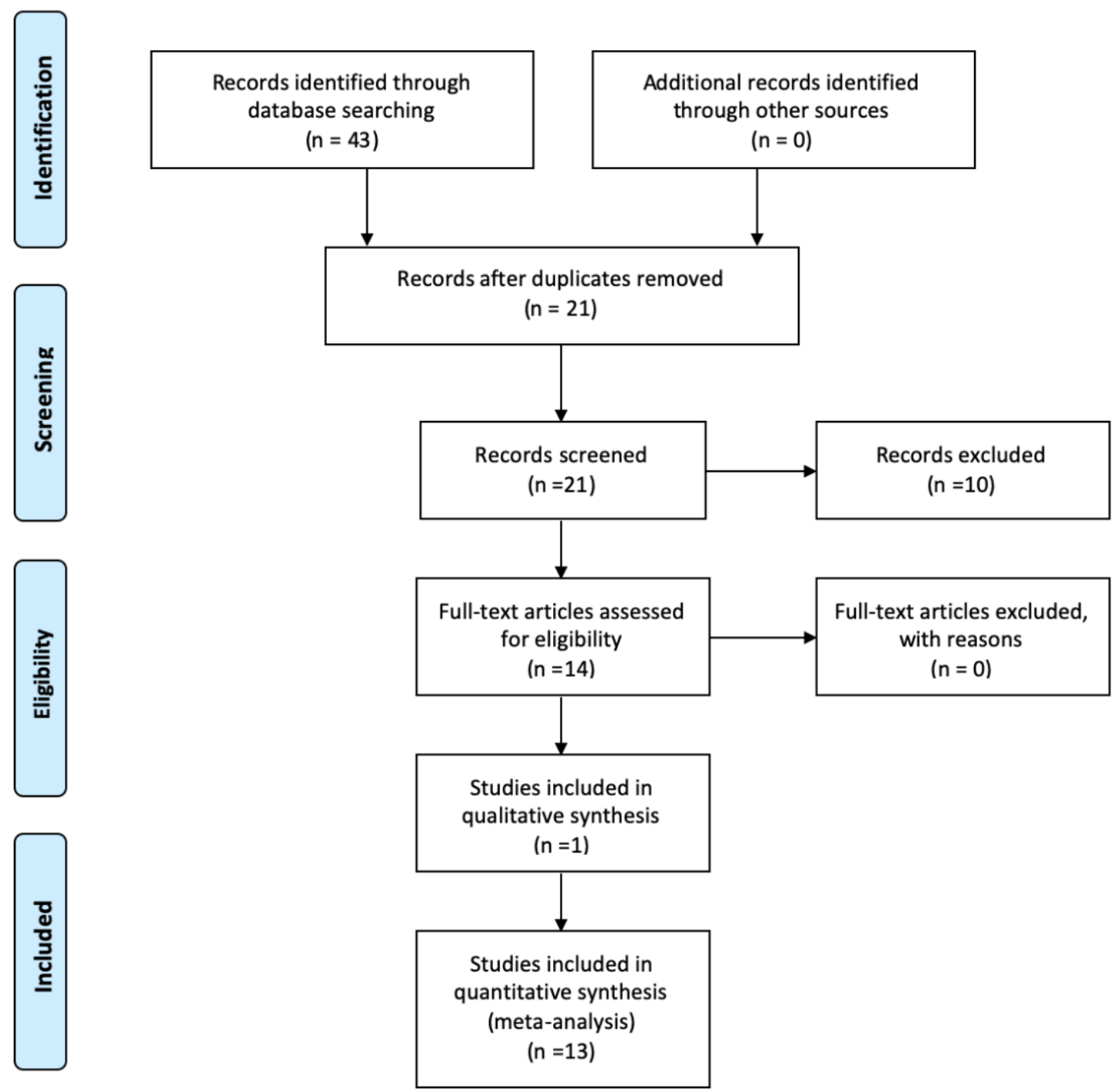
Table 1

Summary of Primary Research Evidence

\begin{tabular}{|c|c|c|c|c|c|c|}
\hline Citation & $\begin{array}{c}\text { Design, } \\
\text { Level } \\
\text { Quality } \\
\text { Grade }\end{array}$ & $\begin{array}{l}\text { Sample } \\
\text { Sample } \\
\text { size }\end{array}$ & $\begin{array}{l}\text { Intervention } \\
\text { Comparison } \\
\text { (Definitions } \\
\text { should include } \\
\text { any specific } \\
\text { research tools } \\
\text { used along } \\
\text { with reliability } \\
\text { \& validity) }\end{array}$ & $\begin{array}{l}\text { Theoretical } \\
\text { Foundation }\end{array}$ & $\begin{array}{l}\text { Outcome } \\
\text { Definition }\end{array}$ & $\begin{array}{c}\text { Usefulness } \\
\text { Results } \\
\text { Key Findings }\end{array}$ \\
\hline $\begin{array}{l}\text { Baker, S. (2010). Rounding for outcomes: An evidence- } \\
\text { based tool to improve nurse retention, patient safety, and } \\
\text { quality of care. Journal of Emergency Nursing, 36(2), } \\
\text { 162-164. https://doi.org/10.1016/j.jen.2009.11.015 }\end{array}$ & $\begin{array}{c}\text { SORT } \\
\text { Level } 2 \\
\\
\text { Quality } \\
\text { Grade of } \\
\text { Moderate }\end{array}$ & \begin{tabular}{|l} 
No \\
human \\
subjects \\
were \\
recruited \\
for study
\end{tabular} & $\begin{array}{l}\text { Implemented } \\
\text { NLR to round } \\
\text { on patients and } \\
\text { staff using a } \\
\text { self-developed } \\
\text { tool to track }\end{array}$ & $\begin{array}{l}\text { No } \\
\text { framework } \\
\text { mentioned }\end{array}$ & $\begin{array}{l}\text { Showed } \\
\text { increase in } \\
\text { patient } \\
\text { satisfaction } \\
\text { scores within } \\
\text { one } \\
\text { department } \\
\text { from } 16^{\text {th }} \text { to } \\
78^{\text {th }} \\
\text { percentile. }\end{array}$ & $\begin{array}{ll}-\quad \text { Standardized } \\
\text { tracking tool } \\
\text { and common } \\
\text { questions. } \\
\text { - } \quad \text { Emphasized } \\
\text { rounding on } \\
\text { staff as well } \\
\text { as patients. }\end{array}$ \\
\hline $\begin{array}{l}\text { Babaev, A. (2017). Nurse leader rounds: Effect on nurse - } \\
\text { related patient satisfaction scores on two post-surgical } \\
\text { units in an acute care facility. (2017). Medical \& Clinical } \\
\text { Research, 2(3). https://doi.org/10.33140/mcr.02.03.02 }\end{array}$ & $\begin{array}{c}\text { SORT } \\
\text { Level } 2 \\
\\
\text { Quality } \\
\text { Grade of } \\
\text { Moderate }\end{array}$ & \begin{tabular}{|l} 
No \\
human \\
subjects \\
were \\
recruited \\
for study
\end{tabular} & $\begin{array}{l}\text { Implementation } \\
\text { of NLR to } \\
\text { increase } \\
\text { HCAHPS } \\
\text { survey scores }\end{array}$ & $\begin{array}{l}\text { Evidence } \\
\text { Based } \\
\text { Leadership }\end{array}$ & $\begin{array}{l}\text { Findings } \\
\text { noted that } \\
\text { patient } \\
\text { satisfaction } \\
\text { increased } \\
\text { when patients } \\
\text { were rounded } \\
\text { on by a } \\
\text { leader. }\end{array}$ & $\begin{array}{l}\text { NLR allows } \\
\text { for connection } \\
\text { with patients } \\
\text { by leader } \\
\text { NLR shows } \\
\text { correlation } \\
\text { with increase } \\
\text { patient } \\
\text { engagement } \\
\text { scores } \\
\end{array}$ \\
\hline $\begin{array}{l}\text { Gillam, S. W., Gillam, A. R., Casler, T. L., \& Cook, K. } \\
\text { (2017). Increasing patient recall of nurse leader rounding. } \\
\text { Applied Nursing Research, 38, 163-168. } \\
\text { https://doi.org/10.1016/j.apnr.2017.10.013 }\end{array}$ & $\begin{array}{c}\text { SORT } \\
\text { Level } 2\end{array}$ & 90 & $\begin{array}{l}\text { NLR to } \\
\text { increase patient } \\
\text { engagement } \\
\text { scores, use of }\end{array}$ & $\begin{array}{l}\text { The paper } \\
\text { followed an } \\
\text { active } \\
\text { learning }\end{array}$ & $\begin{array}{l}\text { After } \\
\text { intervention, } \\
\text { NLR was } \\
\text { recalled by }\end{array}$ & $\begin{array}{l}\text { - } \quad \text { Significance of } \\
\text { NLR and } \\
\text { Patient }\end{array}$ \\
\hline
\end{tabular}




\begin{tabular}{|c|c|c|c|c|c|c|}
\hline & $\begin{array}{l}\text { Quality } \\
\text { Grade of } \\
\text { Moderate }\end{array}$ & & $\begin{array}{l}\text { nurse call } \\
\text { system to help } \\
\text { identify the } \\
\text { nurse leader }\end{array}$ & $\begin{array}{l}\text { design and } \\
\text { did not note } \\
\text { a theoretical } \\
\text { framework. }\end{array}$ & $\begin{array}{l}\text { patients } \\
\text { significantly } \\
\text { greater post } \\
\text { intervention }\end{array}$ & $\begin{array}{l}\text { engagement } \\
\text { scores } \\
\text { - Interventions } \\
\text { to improve } \\
\text { recall by } \\
\text { patients that } \\
\text { NLR was } \\
\text { completed. }\end{array}$ \\
\hline $\begin{array}{l}\text { Hudson-Covolo, J., Rivers, R., \& Irwin, B. (2018). Daily } \\
\text { intentional nurse leader rounding on patients. Journal of } \\
\text { PeriAnesthesia Nursing, 33(1), 90-95. } \\
\text { https://doi.org/10.1016/j/jopan.2017.11.005 }\end{array}$ & $\begin{array}{c}\text { SORT } \\
\text { Level } 2 \\
\\
\text { Quality } \\
\text { Grade of } \\
\text { Moderate }\end{array}$ & $\begin{array}{l}\text { No } \\
\text { human } \\
\text { subjects } \\
\text { identified } \\
\text { within } \\
\text { study }\end{array}$ & $\begin{array}{l}\text { NLR used to } \\
\text { increase patient } \\
\text { satisfaction } \\
\text { scores within } \\
\text { department. }\end{array}$ & $\begin{array}{l}\text { Bloom's } \\
\text { taxonomy }\end{array}$ & $\begin{array}{l}\text { Had } 10 \% \\
\text { increase in } \\
\text { patient } \\
\text { engagement } \\
\text { scores }\end{array}$ & $\begin{array}{ll}\text { - Standard tool } \\
\text { to track } \\
\text { rounding. } \\
\text { - } \quad \text { Tool used to } \\
\text { keep questions } \\
\text { consistent }\end{array}$ \\
\hline $\begin{array}{l}\text { Littleton, L., Fennimore, L., Fernald, C., \& Gonzalez, J. } \\
\text { (2019). Effective nurse leader rounding improves the } \\
\text { patient experience. Nursing Management, 50(10), 11-14. } \\
\text { https://doi.org/10.1097/01.NUMA.0000580620.45628.cd }\end{array}$ & $\begin{array}{c}\text { SORT } \\
\text { Level } 2 \\
\\
\text { Quality } \\
\text { Grade of } \\
\text { Moderate }\end{array}$ & $\begin{array}{l}\text { No } \\
\text { human } \\
\text { subjects } \\
\text { identified } \\
\text { within } \\
\text { study }\end{array}$ & $\begin{array}{l}\text { NLR quantity } \\
\text { was looked at } \\
\text { to see if an } \\
\text { increased } \\
\text { number of } \\
\text { rounds in the } \\
\text { department has } \\
\text { a relationship } \\
\text { with increase } \\
\text { patient } \\
\text { satisfaction } \\
\text { scores }\end{array}$ & $\begin{array}{l}\text { No } \\
\text { framework } \\
\text { mentioned }\end{array}$ & $\begin{array}{l}\text { Showed that } \\
\text { increase nurse } \\
\text { leader } \\
\text { rounding was } \\
\text { a relationship } \\
\text { with an } \\
\text { increased } \\
\text { patient } \\
\text { satisfaction } \\
\text { score }\end{array}$ & $\begin{array}{l}\text { Stated } 50 \% \text { of } \\
\text { all patients in } \\
\text { department } \\
\text { were rounded } \\
\text { in. Only study } \\
\text { to note this. }\end{array}$ \\
\hline $\begin{array}{l}\text { McFarlan, S., O’Brien, D., \& Simmons, E. (2019). Nurse- } \\
\text { leader collaborative improvement project: Improving } \\
\text { patient experience in the emergency department. Journal } \\
\text { of Emergency Nursing, 45(2), 137-143. } \\
\text { https://doi.org/10.1016/j.jen.2018.11.007 }\end{array}$ & $\begin{array}{l}\text { SORT } \\
\text { Level } 2 \\
\text { Quality } \\
\text { Grade of } \\
\text { Moderate }\end{array}$ & $\begin{array}{l}\text { No } \\
\text { human } \\
\text { subjects } \\
\text { identified } \\
\text { within } \\
\text { study }\end{array}$ & $\begin{array}{l}\text { Use of } \\
\text { standardized } \\
\text { NLR process } \\
\text { and } \\
\text { expectations of } \\
\text { leaders within } \\
\text { department. }\end{array}$ & $\begin{array}{l}\text { Kurt } \\
\text { Lewin's } \\
\text { Force Field } \\
\text { Analysis } \\
\text { and Planned } \\
\text { Change } \\
\text { Theory }\end{array}$ & $\begin{array}{l}\text { Results did } \\
\text { not show a } \\
\text { significant } \\
\text { change in } \\
\text { engagement } \\
\text { scores. } \\
\text { Limitations } \\
\text { related to } \\
\text { study } \\
\text { outcomes, } \\
\text { leadership } \\
\text { changes, flu } \\
\text { season, and }\end{array}$ & 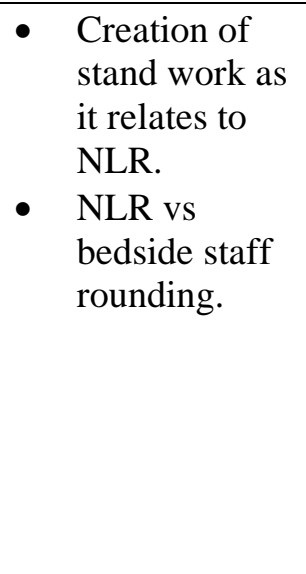 \\
\hline
\end{tabular}




\begin{tabular}{|c|c|c|c|c|c|c|}
\hline & & & & & $\begin{array}{l}\text { MSN students } \\
\text { no longer able } \\
\text { to assist. }\end{array}$ & \\
\hline $\begin{array}{l}\text { Morton, J. C., Brekhus, J., Reynolds, M., \& Dykes, A. } \\
\text { (2014). Improving the patient experience through nurse } \\
\text { leader rounds. Patient Experience Journal, l(2), 53-61. } \\
\text { https://doi.org/10.35680/2372-0247.1036 }\end{array}$ & $\begin{array}{l}\text { SORT } \\
\text { Level } 2 \\
\text { Quality } \\
\text { Grade of } \\
\text { Moderate }\end{array}$ & 39006 & $\begin{array}{l}\text { Use of } \\
\text { standardized } \\
\text { NLR process }\end{array}$ & $\begin{array}{l}\text { Paper did } \\
\text { not speak to } \\
\text { framework }\end{array}$ & $\begin{array}{l}\text { Findings } \\
\text { found a } \\
\text { significant } \\
\text { relationship } \\
\text { between NLR } \\
\text { and patient } \\
\text { satisfaction } \\
\text { scores. }\end{array}$ & 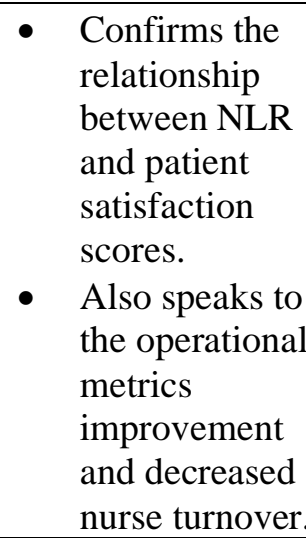 \\
\hline $\begin{array}{l}\text { Pattison, K. H., Heyman, A., Barlow, J., \& Barrow, K. } \\
\text { (2017). Patient perceptions of sitting versus standing for } \\
\text { nurse leader rounding. Journal of Nursing Care Quality, } \\
\text { 32(1), 1-5. } \\
\text { https://doi.org/10.1097/ncq.0000000000000214 }\end{array}$ & $\begin{array}{l}\text { SORT } \\
\text { Level } 2 \\
\text { Quality } \\
\text { Grade of } \\
\text { Moderate }\end{array}$ & 84 & $\begin{array}{l}\text { Study looked at } \\
\text { the differences } \\
\text { in patient } \\
\text { perception } \\
\text { when standing } \\
\text { vs sitting as a } \\
\text { leader during } \\
\text { rounding }\end{array}$ & $\begin{array}{l}\text { No } \\
\text { framework } \\
\text { mentioned }\end{array}$ & $\begin{array}{l}\text { Study showed } \\
\text { that patients } \\
\text { perception } \\
\text { leaders in the } \\
\text { room } \\
\text { significantly } \\
\text { longer when } \\
\text { sitting vs } \\
\text { standing }\end{array}$ & $\begin{array}{l}\text { - Study showed } \\
\text { that standing } \\
\text { vs sitting did } \\
\text { not have } \\
\text { relationship } \\
\text { with } \\
\text { satisfaction by } \\
\text { patient during } \\
\text { rounding } \\
\text { - Study showed } \\
\text { that when } \\
\text { sitting vs } \\
\text { standing, } \\
\text { patient feels } \\
\text { leader is in } \\
\text { room longer }\end{array}$ \\
\hline $\begin{array}{l}\text { Reid, S. (2017). Improving patient satisfaction scores with } \\
\text { digital nurse leader rounding. Health Management } \\
\text { Technology, 14. www.healthmgttech.com }\end{array}$ & $\begin{array}{l}\text { SORT } \\
\text { Level } 2 \\
\text { Quality } \\
\text { Grade of } \\
\text { Moderate }\end{array}$ & $\begin{array}{l}\text { No } \\
\text { human } \\
\text { subjects } \\
\text { identified } \\
\text { within } \\
\text { study }\end{array}$ & $\begin{array}{l}\text { Study looked } \\
\text { into the use of } \\
\text { electronic tools } \\
\text { while leader } \\
\text { rounding. }\end{array}$ & $\begin{array}{l}\text { No } \\
\text { framework } \\
\text { mentioned }\end{array}$ & $\begin{array}{l}\text { Study showed } \\
\text { significant } \\
\text { improvements } \\
\text { in patient } \\
\text { satisfaction } \\
\text { during NLR }\end{array}$ & 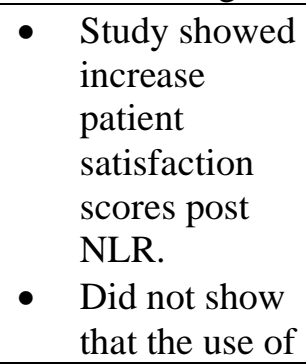 \\
\hline
\end{tabular}




\begin{tabular}{|c|c|c|c|c|c|c|}
\hline & & & & & & $\begin{array}{l}\text { electronic tool } \\
\text { had } \\
\text { relationship } \\
\text { with patient } \\
\text { scores }\end{array}$ \\
\hline $\begin{array}{l}\text { Setia, N., \& Meade, C. (2009). Bundling the value of } \\
\text { discharge telephone calls and leader rounding. JONA: The } \\
\text { Journal of Nursing Administration, 39(3), 138-141. } \\
\text { https://doi.org/10.1097/nna.0b013e31819894f1 }\end{array}$ & $\begin{array}{l}\text { SORT } \\
\text { Level } 2 \\
\text { Quality } \\
\text { Grade of } \\
\text { Moderate }\end{array}$ & $\begin{array}{l}\text { No } \\
\text { human } \\
\text { subjects } \\
\text { identified } \\
\text { within } \\
\text { study }\end{array}$ & $\begin{array}{l}\text { Study looked at } \\
\text { the two } \\
\text { interventions of } \\
\text { post discharge } \\
\text { phone calls and } \\
\text { NLR. }\end{array}$ & $\begin{array}{l}\text { No } \\
\text { framework } \\
\text { was } \\
\text { mentioned }\end{array}$ & $\begin{array}{l}\text { Showed that } \\
\text { while each } \\
\text { individual } \\
\text { tactic is } \\
\text { effective in } \\
\text { increase } \\
\text { patient } \\
\text { engagement } \\
\text { scores. The } \\
\text { two tactics } \\
\text { together show } \\
\text { the best } \\
\text { outcomes for } \\
\text { patient } \\
\text { engagement }\end{array}$ & $\begin{array}{l}\text { - Study showed } \\
\text { the outcome of } \\
\text { using NLR and } \\
\text { post discharge } \\
\text { phone calls. }\end{array}$ \\
\hline $\begin{array}{l}\text { Sturdivant, T., Herrin, K., Reynolds, M., \& Mestas, L. } \\
\text { (2020). Improving patient satisfaction through a nurse } \\
\text { leader-Physician bedside rounding protocol: A pilot } \\
\text { project. Nursing Economics, 38(3), 158-163. } \\
\text { http://www.nursingeconomics.net/cgi- } \\
\text { bin/WebObjects/NECJournal.woa }\end{array}$ & $\begin{array}{l}\text { SORT } \\
\text { Level } 2 \\
\text { Quality } \\
\text { Grade of } \\
\text { Moderate }\end{array}$ & 118 & $\begin{array}{l}\text { Study looked at } \\
\text { both NLR and } \\
\text { physician } \\
\text { leader } \\
\text { rounding. }\end{array}$ & $\begin{array}{l}\text { No } \\
\text { framework } \\
\text { was } \\
\text { mentioned }\end{array}$ & $\begin{array}{l}\text { Study looked } \\
\text { into the use of } \\
\text { both NLR and } \\
\text { physician } \\
\text { leader } \\
\text { rounding. } \\
\text { Study did not } \\
\text { show } \\
\text { significant } \\
\text { increases in } \\
\text { patient } \\
\text { engagement } \\
\text { scores }\end{array}$ & $\begin{array}{l}\text { - Study rounded } \\
\text { on small } \\
\text { percentage of } \\
\text { patients. } \\
\text { - Study saw } \\
\text { communication } \\
\text { scores increase } \\
\text { in both nurse } \\
\text { and physician } \\
\text { domain but not } \\
\text { overall ranking }\end{array}$ \\
\hline $\begin{array}{l}\text { Tothy, A., Sastry, S. K., Springman, M. K., Limper, H. } \\
\text { M., Fahrenbach, J., \& Murphy, S. M. (2018). } \\
\text { Transforming care through bedside leader rounding: Use } \\
\text { of handheld technology leads to improvement in } \\
\text { perceived patient satisfaction. Patient Experience }\end{array}$ & $\begin{array}{l}\text { SORT } \\
\text { Level } 2 \\
\text { Quality } \\
\text { Grade of } \\
\text { Moderate }\end{array}$ & 25984 & $\begin{array}{l}\text { Study } \\
\text { intervention } \\
\text { was related to } \\
\text { the use of } \\
\text { handheld } \\
\text { devices that } \\
\text { prompted nurse }\end{array}$ & $\begin{array}{l}\text { The paper } \\
\text { did not use } \\
\text { a theoretical } \\
\text { framework }\end{array}$ & $\begin{array}{l}\text { NLR was } \\
\text { shown to } \\
\text { have a } \\
\text { significant } \\
\text { increase in } \\
\text { overall } \\
\text { patient }\end{array}$ & 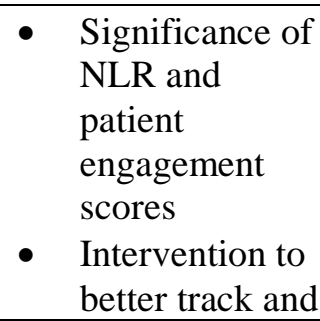 \\
\hline
\end{tabular}




\begin{tabular}{|c|c|c|c|c|c|c|}
\hline $\begin{array}{l}\text { Journal, 5(3), 41-46. https://doi.org/10.35680/2372- } \\
\underline{0247.1254}\end{array}$ & & & $\begin{array}{l}\text { leader with } \\
\text { standardized } \\
\text { questions to } \\
\text { use during } \\
\text { rounding. }\end{array}$ & & $\begin{array}{l}\text { engagement. } \\
\text { However, the } \\
\text { use of } \\
\text { technology to } \\
\text { standardize } \\
\text { process did } \\
\text { not show } \\
\text { significance } \\
\text { in recall of } \\
\text { NLR }\end{array}$ & $\begin{array}{l}\text { standardize } \\
\text { NLR process } \\
\text { - Outcomes of } \\
\text { increased } \\
\text { patient } \\
\text { engagement } \\
\text { scores and no } \\
\text { significance in } \\
\text { recall of NLR } \\
\text { by use of } \\
\text { technology in } \\
\text { rounds }\end{array}$ \\
\hline $\begin{array}{l}\text { Winter, M., \& Tjiong, L. (2015). Hcahps series part } 2 . \\
\text { Nursing Management (Springhouse), 46(2), 26-32. } \\
\text { https://doi.org/10.1097/01.numa.0000460034.25697.06 }\end{array}$ & $\begin{array}{c}\text { SORT } \\
\text { Level } 2 \\
\\
\text { Quality } \\
\text { Grade of } \\
\text { Moderate }\end{array}$ & 2506 & $\begin{array}{l}\text { Study looked at } \\
\text { the intervention } \\
\text { of NLR to } \\
\text { increase patient } \\
\text { engagement } \\
\text { scores }\end{array}$ & $\begin{array}{l}\text { Framework } \\
\text { was not } \\
\text { mentioned } \\
\text { in paper }\end{array}$ & $\begin{array}{l}\text { This study } \\
\text { showed } \\
\text { improvement } \\
\text { in various } \\
\text { questions } \\
\text { related to } \\
\text { patient } \\
\text { engagement, } \\
\text { however did } \\
\text { not show } \\
\text { improvement } \\
\text { in the overall } \\
\text { ranking of the } \\
\text { department. }\end{array}$ & 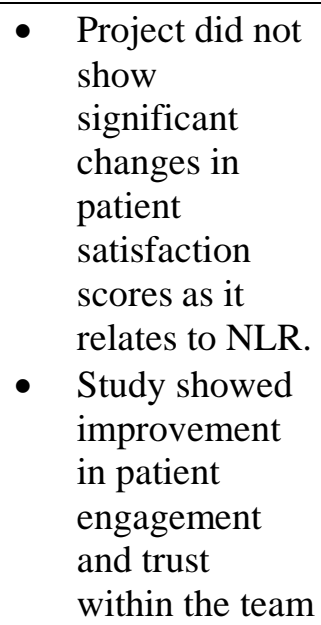 \\
\hline
\end{tabular}


Table 2

Summary of Systematic Reviews (SR)

\begin{tabular}{|c|c|c|c|c|c|c|c|}
\hline$\overline{\text { Citation }}$ & $\begin{array}{l}\text { Quality } \\
\text { Grade }\end{array}$ & Question & Search Strategy & $\begin{array}{l}\text { Inclusion/ } \\
\text { Exclusion Criteria }\end{array}$ & \begin{tabular}{|l|} 
Data Extraction and \\
Analysis
\end{tabular} & $\overline{K e y}$ Findings & $\begin{array}{l}\text { Usefulness/Recom } \\
\text { mendation/ } \\
\text { Implications }\end{array}$ \\
\hline $\begin{array}{l}\text { Tan, M., \& Lang, } \\
\text { D. (2014). } \\
\text { Effectiveness of } \\
\text { nurse leader } \\
\text { rounding and post- } \\
\text { discharge } \\
\text { telephone calls on } \\
\text { patient } \\
\text { satisfaction: A } \\
\text { systematic review } \\
\text { protocol. JBI } \\
\text { Database of } \\
\text { Systematic } \\
\text { Reviews and } \\
\text { Implementation } \\
\text { Reports, 12(1), } \\
\text { 23-32. } \\
\text { https://doi.org/10.1 } \\
1124 / \text { jbisrir-2014- } \\
1256\end{array}$ & Moderate & \begin{tabular}{l|} 
What is the \\
effectiveness \\
of nurse \\
leader \\
rounding and \\
follow-up, \\
discharge \\
phone calls \\
on patient \\
satisfaction \\
with hospital?
\end{tabular} & $\begin{array}{l}\text { Was to find both } \\
\text { published and } \\
\text { unpublished } \\
\text { studies. Three- } \\
\text { step search } \\
\text { strategy will be } \\
\text { utilized. Use of } \\
\text { MEDLINE and } \\
\text { CINAHL, use of } \\
\text { keywords, and } \\
\text { then the use of } \\
\text { found article's } \\
\text { reference lists. }\end{array}$ & $\begin{array}{l}\text { Inclusion: adult patients } \\
\text { who have experienced } \\
\text { hospital services. Nurse } \\
\text { Leader Rounding and Post } \\
\text { discharge call } \\
\text { Patient satisfaction as type } \\
\text { of outcome. Review all } \\
\text { experimental study designs } \\
\text { Exclusion: Settings in } \\
\text { outpatient clinics }\end{array}$ & \begin{tabular}{|l|} 
Used the data \\
extraction tool from \\
JBI-MAStARI. \\
Synthesis of the data \\
was quantitative in \\
statistical meta- \\
analysis. Use of a \\
$95 \%$ confidence \\
interval while using a \\
standard chi-square.
\end{tabular} & $\begin{array}{l}\text { NLR has a } \\
\text { correlation with } \\
\text { patient satisfaction } \\
\text { scores. }\end{array}$ & \\
\hline
\end{tabular}


Table 3

SWOT Analysis

\begin{tabular}{lccc}
\hline Strengths & Weaknesses & Opportunities & Threats \\
\hline $\begin{array}{l}\text { Chief Nursing Officer } \\
\text { Approval and support }\end{array}$ & $\begin{array}{c}\text { Unit manage with } \\
\text { large span of control }\end{array}$ & $\begin{array}{c}\text { Highly engaged } \\
\text { system patient } \\
\text { engagement director }\end{array}$ & $\begin{array}{c}\text { System } \\
\text { standardization which } \\
\text { may conflict with } \\
\text { project proposal }\end{array}$ \\
$\begin{array}{l}\text { Entity patient } \\
\text { engagement manager } \\
\text { support }\end{array}$ & $\begin{array}{c}\text { New leadership team } \\
\text { within unit }\end{array}$ & $\begin{array}{c}\text { System VP of nursing } \\
\text { operations support of } \\
\text { nursing leadership }\end{array}$ & $\begin{array}{c}\text { System priorities } \\
\text { related to patient } \\
\text { engagement }\end{array}$ \\
$\begin{array}{l}\text { Unit manager with } \\
\text { passion for patient } \\
\text { engagement }\end{array}$ & & & \\
& & & \\
\hline
\end{tabular}


Table 4

\section{Collected Variables}

\begin{tabular}{|c|c|c|}
\hline Variable & Source of Variable & Analysis \\
\hline $\begin{array}{l}\text { Likelihood of your } \\
\text { recommending...to others }\end{array}$ & Press Ganey Survey & Mean, percentage, indep. t-test \\
\hline Nurses' concern... your treatment & Press Ganey Survey & Mean, percentage, indep. t-test \\
\hline Overall rating of...your visit & Press Ganey Survey & Mean, percentage, indep. t-test \\
\hline $\begin{array}{l}\text { Date of visit with completed } \\
\text { survey }\end{array}$ & Press Ganey Survey & Mean, percentage, indep. t-test \\
\hline $\begin{array}{l}\text { Time of visit with completed } \\
\text { survey }\end{array}$ & Press Ganey Survey & Mean, percentage \\
\hline Leader completing rounds & Data Collection Tool & Mean, percentage \\
\hline Date of completed rounds & Data Collection Tool & Mean, percentage \\
\hline Time of completed rounds & Data Collection Tool & Mean, percentage \\
\hline Number of completed rounds & Data Collection Tool & Mean, percentage \\
\hline Compliance of process & Data collection tool & Mean, percentage \\
\hline Total time specific ED volume & Department leadership & $\begin{array}{l}\text { Point Biserial Correlations with } \\
\text { completed rounds, and question } \\
\text { responses }\end{array}$ \\
\hline
\end{tabular}


Appendix A

Nurse Leader Rounding Validation Tool

\section{Nurse Leader Rounding Program}

Nurse Leader Rounding Competency/Validation

Name:

Instructions:

1. Nurse Leaders are to complete the self-assessment portion of the document at the training

2. The Project Lead will observe 5 observations of the Nurse Leader Rounding on patients in order to

3. The Project lead to provide feedback and correction if needed.

\begin{tabular}{|l|l|l|l|l|l|}
\hline \multicolumn{2}{|c|}{ Performance Criteria } & \multicolumn{3}{l|}{$\begin{array}{l}\text { Self- } \\
\text { Assessment }\end{array}$} & \multicolumn{3}{l|}{ Evaluator's Assessment } \\
\cline { 2 - 6 } & & & & & \\
\hline "I am washing my hands for your safety" & & & & & \\
\hline Acknowledges patient and family & & & & & \\
\hline Introduction & & & & & \\
\hline Explains the purpose of rounding to patient and duration & & & & & \\
\hline Managers up care team & & & & & \\
\hline Verifies patient has been kept informed about plan of care & & & & & \\
\hline Verifies staff has been courteous and explaining the process & & & & & \\
\hline Invites recognition of care team & & & & & \\
\hline Assess environment including cleanliness, safety & & & & & \\
\hline Thanks the patient for opportunity to care for them & & & & & \\
\hline $\begin{array}{l}\text { Recognizes if appropriate the need for service recovery using } \\
\text { GIFT (gather, I'm sorry, follow up, and thank you) }\end{array}$ & & & & & \\
\hline $\begin{array}{l}\text { Provides specific feedback/recognition based on patient } \\
\text { feedback and leader observations }\end{array}$ & & & & & \\
\hline
\end{tabular}


Appendix B

Project Schedule NUR7801

\begin{tabular}{|c|c|c|c|c|c|c|c|c|c|c|c|c|c|c|c|}
\hline & \multicolumn{14}{|c|}{ NUR7801: May $11^{\text {th }}, 2020-$ August $19^{\text {th }}, 2020$} & \\
\hline 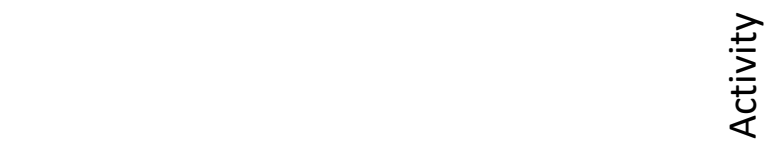 & 离 & $\begin{array}{l}\frac{N}{0} \\
\frac{\pi}{3}\end{array}$ & $\begin{array}{l}m \\
\frac{m}{0} \\
3\end{array}$ & 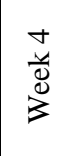 & $\begin{array}{l}n \\
\stackrel{0}{0} \\
\stackrel{0}{3}\end{array}$ & $\begin{array}{l}0 \\
\text { "ूँ } \\
3\end{array}$ & 离 & $\begin{array}{l}\infty \\
\stackrel{\infty}{0} \\
\stackrel{y}{3}\end{array}$ & 竧 & $\begin{array}{l}0 \\
\frac{u}{0} \\
3\end{array}$ & $\begin{array}{l}= \\
\text { ü } \\
3\end{array}$ & $\begin{array}{l}\stackrel{\Xi}{J} \\
\stackrel{\Xi}{J} \\
3\end{array}$ & $\begin{array}{l}\frac{m}{U} \\
\frac{u}{0} \\
3\end{array}$ & 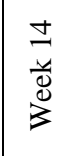 & $\begin{array}{l}\frac{n}{n} \\
\frac{\pi}{0} \\
3\end{array}$ \\
\hline Meet with Preceptor & $\mathrm{x}$ & & $\mathrm{x}$ & & $\mathrm{x}$ & & $\mathrm{x}$ & & $\mathrm{x}$ & & $\mathrm{x}$ & & $\mathrm{x}$ & & $\mathrm{x}$ \\
\hline Prepare Project Proposal requirements & $\mathrm{x}$ & $x$ & $\mathrm{x}$ & $x$ & $\mathrm{x}$ & $\mathrm{x}$ & $\mathrm{x}$ & $x$ & $x$ & $\mathrm{x}$ & $x$ & $x$ & $\mathrm{x}$ & $\mathrm{x}$ & $x$ \\
\hline Meet with CNO for project approval & & & & $\mathrm{x}$ & & & & & & & & & & & \\
\hline $\begin{array}{l}\text { Meet with Patient Experience manager for } \\
\text { approval and support }\end{array}$ & & & & & $\mathrm{x}$ & & & & & & & & & & \\
\hline $\begin{array}{l}\text { Meet with Quality Director for Approval and } \\
\text { support }\end{array}$ & & & & & $\mathrm{x}$ & & & & & & & & & & \\
\hline $\begin{array}{l}\text { Meet with system patient experience } \\
\text { director for support }\end{array}$ & & & & & & & & & $\mathrm{x}$ & & & & & & \\
\hline
\end{tabular}


Appendix C

Project Schedule NUR7802

\begin{tabular}{|c|c|c|c|c|c|c|c|c|c|c|c|c|c|c|c|}
\hline & \multicolumn{14}{|c|}{ NUR7802: September $8^{\text {th }}, 2020$ - December $19^{\text {th }}, 2020$} & \\
\hline 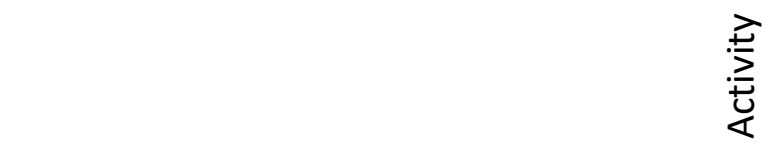 & $\frac{\vec{u}}{\frac{\pi}{3}}$ & $\begin{array}{l}\frac{v}{d} \\
\frac{u}{3}\end{array}$ & $\begin{array}{l}\frac{n}{\tilde{J}} \\
\frac{\tilde{J}}{3}\end{array}$ & 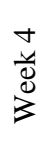 & $\begin{array}{l}n \\
\frac{y}{0} \\
\frac{0}{3}\end{array}$ & $\begin{array}{l}0 \\
\frac{y}{d} \\
0 \\
3\end{array}$ & $\frac{n}{\frac{u}{0}}$ & $\begin{array}{l}\infty \\
\frac{u}{0} \\
\ddot{J}\end{array}$ & $\begin{array}{l}a \\
\frac{a}{0} \\
3\end{array}$ & $\begin{array}{l}0 \\
\frac{1}{8} \\
3\end{array}$ & $\begin{array}{l}= \\
\frac{u}{d} \\
3\end{array}$ & $\begin{array}{l}\stackrel{J}{\frac{1}{d}} \\
\frac{d}{3}\end{array}$ & $\begin{array}{l}\frac{m}{8} \\
\frac{\pi}{3}\end{array}$ & $\begin{array}{l} \pm \\
\frac{J}{d} \\
\frac{d}{3}\end{array}$ & $\begin{array}{l}n \\
\check{\pi} \\
\frac{\pi}{3}\end{array}$ \\
\hline Meet with Preceptor & $\mathrm{X}$ & & $\mathrm{X}$ & & $x$ & & $\mathrm{X}$ & & $\mathrm{X}$ & & $\mathrm{X}$ & & $x$ & & $\mathrm{X}$ \\
\hline Gain IRB Approval & $\mathrm{X}$ & $\mathrm{X}$ & $\mathrm{X}$ & & & & & & & & & & & & \\
\hline Meet with identified project team & $\mathrm{X}$ & $\mathrm{X}$ & $\mathrm{X}$ & $x$ & $\mathrm{X}$ & $\mathrm{X}$ & $\mathrm{X}$ & $\mathrm{X}$ & $\mathrm{X}$ & $\mathrm{X}$ & $\mathrm{X}$ & $x$ & $\mathrm{X}$ & $x$ & $\mathrm{X}$ \\
\hline $\begin{array}{l}\text { Complete education with project team CNM } \\
\text { and ANM }\end{array}$ & & $\mathrm{X}$ & & & & & & & & & & & & & \\
\hline $\begin{array}{l}\text { Complete validation of process by project } \\
\text { lead }\end{array}$ & & & $\mathrm{X}$ & & & & & & & & & & & & \\
\hline Implement NLR & & & & $\mathrm{X}$ & & & & & & & & & & & \\
\hline Completion of NLR & & & & & $x$ & $x$ & $x$ & $x$ & $x$ & $x$ & $x$ & & & & \\
\hline Collection of Press Ganey for NLR & & & & & $x$ & $x$ & $x$ & $x$ & $x$ & $x$ & $\mathrm{X}$ & $x$ & $X$ & $x$ & $x$ \\
\hline
\end{tabular}


Appendix D

Project Schedule NUR7803

\begin{tabular}{|c|c|c|c|c|c|c|c|c|c|c|c|c|c|c|c|}
\hline & \multicolumn{14}{|c|}{ NUR7803: January $11^{\text {th }}, 2021-$ April $24^{\text {th }}, 2021$} & \\
\hline 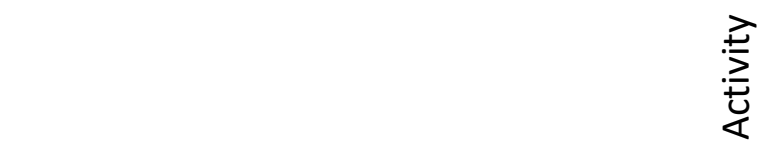 & $\frac{\bar{d}}{3}$ & $\begin{array}{l}\frac{1}{d} \\
\frac{u}{3} \\
0\end{array}$ & $\begin{array}{l}m \\
\frac{m}{8} \\
3\end{array}$ & 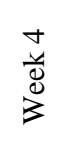 & $\begin{array}{l}n \\
\frac{x}{0} \\
3 \\
3\end{array}$ & $\begin{array}{l}0 \\
\frac{0}{0} \\
3\end{array}$ & $\frac{\bar{v}}{\bar{d}}$ & $\begin{array}{l}\infty \\
\frac{1}{0} \\
3\end{array}$ & $\begin{array}{l}\frac{a}{\Xi} \\
\frac{\ddot{u}}{3}\end{array}$ & $\begin{array}{l}\stackrel{0}{1} \\
\frac{u}{\Xi} \\
\frac{d}{3}\end{array}$ & $\begin{array}{l}= \\
\frac{u}{\Delta} \\
3\end{array}$ & $\begin{array}{l}\frac{7}{d} \\
\frac{\pi}{2}\end{array}$ & $\begin{array}{l}m \\
\frac{\pi}{\pi} \\
3\end{array}$ & $\begin{array}{l}J \\
\frac{J}{J} \\
3\end{array}$ & $\begin{array}{l}n \\
\frac{n}{d} \\
3\end{array}$ \\
\hline Meet with Preceptor & $\mathrm{X}$ & & $\mathrm{X}$ & & $\mathrm{X}$ & & $X$ & & $x$ & & $\mathrm{X}$ & & $\mathrm{X}$ & & $x$ \\
\hline Meet with identified project team & $x$ & $x$ & $x$ & $x$ & $x$ & $x$ & $X$ & $x$ & $x$ & $x$ & $x$ & $x$ & $x$ & $x$ & \\
\hline Analysis of data & $\mathrm{x}$ & $\mathrm{X}$ & $X$ & & & & & & & & & & & & \\
\hline Preparation of final document & $\mathrm{X}$ & & & $\mathrm{X}$ & $\mathrm{X}$ & $\mathrm{X}$ & & & & & & & & & \\
\hline $\begin{array}{l}\text { Presentation of data to project team and } \\
\text { executives }\end{array}$ & & & & & & & $X$ & $\mathrm{X}$ & & & & & & & \\
\hline Completion of find document & & & & & & & & & $\mathrm{X}$ & $\mathrm{X}$ & & & & & \\
\hline Celebration of completion & & & & & & & & & $\mathrm{x}$ & & $\mathrm{X}$ & $\mathrm{X}$ & $x$ & $x$ & $\mathrm{X}$ \\
\hline
\end{tabular}


Appendix E

Nurse Leader Rounding Data Collection Tool

\section{Nurse Leader Rounding Checklist}

Data Collection Tool

Rounder

Date

Time Started

Number of Rounds Completed

Completed on all rounds:

\section{Performance Criteria}

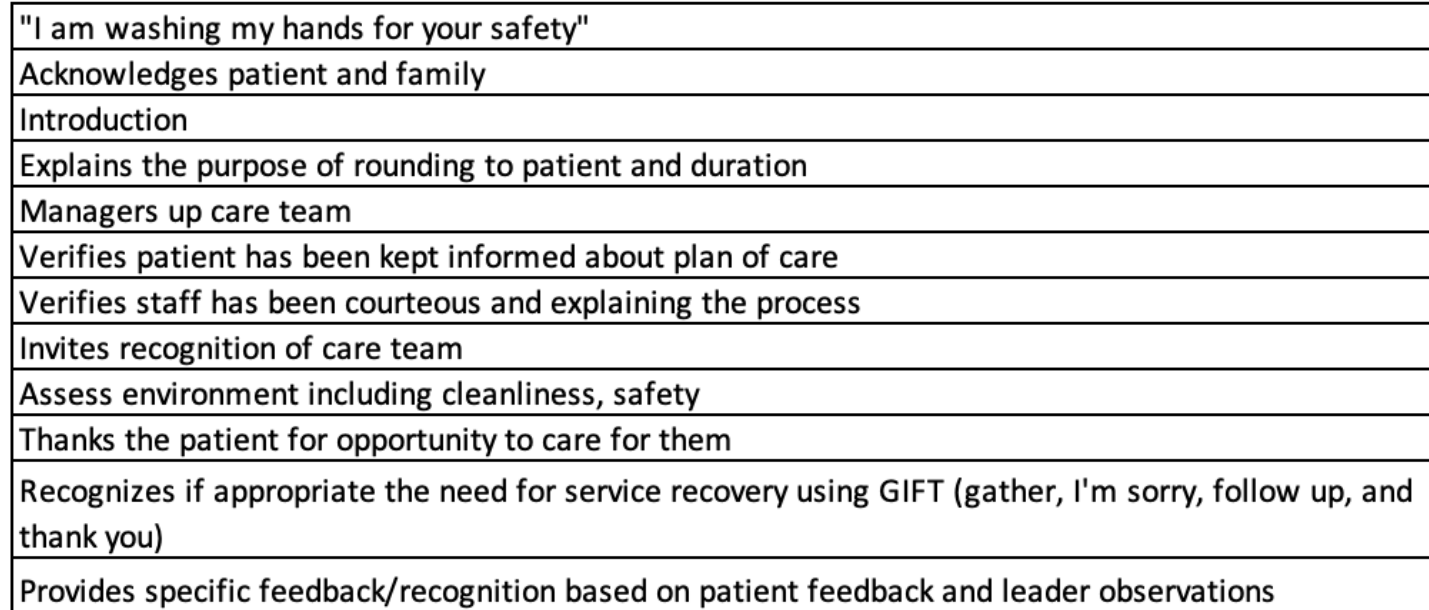

\begin{tabular}{l} 
Patient Initials Room \# $\quad$ Nurse \\
\hline
\end{tabular}

